\title{
DETERMINATION OF FETAL RHESUS D STATUS BY MATERNAL PLASMA DNA ANALYSIS
}

\author{
Aykut $\mathrm{A}^{1, *}$, Onay $\mathrm{H}^{1}$, Sagol $\mathrm{S}^{2}$, Gunduz $\mathrm{C}^{3}$, Ozkinay $\mathrm{F}^{1}$, Cogulu $\mathrm{O}^{1}$
}

*Corresponding Author: Ayça Aykut, M.D., Ph.D., Department of Medical Genetics, Ege University Faculty of Medicine, 35100, Bornova, Izmir, Turkey; Tel.: +90-232-390-3961; Fax: +90-232-390-3971; E-mail: aycaaykut@hotmail.com

\section{ABSTRACT}

In this study, we assessed the feasibility of fetal RhD genotyping by analysis of cell-free fetal DNA(cffDNA) extracted from plasma samples of Rhesus (Rh) D-negative pregnant women by using real-time polymerase chain reaction (PCR). Fetal genotyping was performed on $30 \mathrm{RhD}$-negative women between 9 and 39 weeks of gestation who were referred to us for invasive testing [amniocentesis/chorionic villi sampling (CVS)]. The fetal RHD genotype was determined based on real-time PCR method. Exons 7 and 10 of the RHD and $S R Y$ genes were targeted.

Among the pregnant women, 12 were carrying male and 17 were carrying female fetuses. Out of 29 pregnant women, 21 had $\mathrm{RhD}$-positive and nine had RhD-negative fetuses. One sample )case 12 , whose blood group was found to be $\mathrm{AB} \mathrm{Rh}[+]$ (was excluded due to controversial results from repeated serological analyses. All prenatal results were in concordance with postnatal $\mathrm{RhD}$ status and fetal sex without false- positive or -negative results. Performing real-time PCR on cffDNA showed accurate, efficient and reliable results, allowing rapid and high

\footnotetext{
${ }^{1}$ Department of Medical Genetics, Ege University, Faculty of Medicine, Bornova, Izmir, Turkey

${ }^{2}$ Department of Obstetrics and Gynecology, Ege University, Faculty of Medicine, Bornova, Izmir, Turkey

${ }^{3}$ Department of Medical Biology, Ege University, Faculty of Medicine, Bornova, Izmir, Turkey
}

throughput non invasive determination of fetal sex and $\mathrm{RhD}$ status in clinical samples.

Keywords: Rhesus D (RhD); Non invasive prenatal diagnosis.

\section{INTRODUCTION}

Rhesus D (RhD) alloimmunization still remains the major cause of severe hemolytic disease in fetuses and newborns (HDFN), which may lead to anemia, hydrops fetalis and intrauterine fetal death. The incidence of HDFN has been reduced by anti$\mathrm{RhD}$ prophylaxis at the 28th and 34th week of gestation. Therefore, the demonstration of fetal D status is very important in the management of HDFN. Accurate prediction of the fetal $\mathrm{RhD}$ type provides prenatal prophylaxis in $\mathrm{RhD}$-negative women with an $\mathrm{RhD}$-positive fetus (about $40.0 \%$ ) from unnecessary administration of anti $\mathrm{D}$. The most common cause of $\mathrm{RhD}$ negativity is the absence of the $R H D$ gene [1]. Consequently, most genotyping strategies are based on detecting the presence or absence of the RHD gene.

An $\mathrm{RhD}$ status of the fetus can be detected by invasive methods of prenatal diagnostic tests such as amniocentesis and chorionic villus sampling (CVS) that require fetal tissue but may result in miscarriage or risk of increased maternal sensitization because of complications attributed to CVS or amniocentesis. Recent studies have focused on new non invasive prenatal diagnostic techniques such as circulating fetal nucleic acids in maternal plasma to develop 
reliable non invasive tests for clinical prenatal diagnosis for RhD status of the fetus [2-8]. In this study, we assessed the feasibility of fetal gender and RHD genotyping in the plasma samples of $\mathrm{RhD}$-negative pregnant women by using primers and probes targeted toward the $S R Y$ gene and exons 7 and 10 of the RHD gene.

\section{MATERIALS AND METHODS}

Blood samples ( $9 \mathrm{~mL})$, collected in EDTA vacutainers, from $30 \mathrm{RhD}$-negative Turkish women between 9 and 39 weeks of gestation, who were referred to us for invasive testing because of advanced maternal age, increased maternal serum screening test, fetal sonographic abnormality and previous history of chromosomal or single gene disorder. Routine assay for $\mathrm{ABO}$ and $\mathrm{RhD}$ typing and testing for unexpected antibodies were performed to include $\mathrm{RhD}$ negative women in the study. The positive control for the RHD and SRY genes was a heterozygous $R H D$-positive man, while the negative control for both genes was an $\mathrm{RhD}$-negative non pregnant woman. The $S R Y$ gene served as an internal control marker to confirm the presence of male fetal DNA. All analyses were performed blind, that is, the fetal RHD genotyping was performed without knowing the fetus RhD status, which was confirmed by serological methods postpartum. Nine $\mathrm{mL}$ of maternal blood was collected in EDTA vacutainers and sent to the laboratory at room temperature. The blood was centrifuged at $2840 \mathrm{rpm}$ for $10 \mathrm{~min}$., the plasma was transferred without disturbing the buffy coat and recentrifuged again at $3600 \mathrm{rpm}$ for $20 \mathrm{~min}$. and the supernatants were collected and stored at $-80^{\circ} \mathrm{C}$ before DNA extraction.

Written informed consent was obtained from all the families. The study was approved by the Faculty Ethics Committee of Ege University Faculty of Medicine, Izmir, Turkey.

DNA Extraction from Plasma Samples and Fetal Samples. DNA was extracted from $500 \mu \mathrm{L}$ plasma using QIAamp DSP Virus Kit (Qiagen, Hilden, Germany) according to the manufacturer's instructions. DNA was eluted in 20 Elution buffer (AVE) and $4.0 \mu \mathrm{L}$ was used as a template for the polymerase chain reaction (PCR).

DNA from amniocentesis or CVS specimens was isolated using Chelex (InstaGene Matrix ${ }^{\mathrm{TM}}$, Bio-Rad Laboratories, Mississauga, Ontario, Canada) in a rapid isolation technique according to the manufacturer's instructions. The specimens were stored at $-20^{\circ} \mathrm{C}$ before being studied.

Real-time Polymerase Chain Reaction Analysis. The TaqMan real-time PCR assay protocol (LightCycler 1.5, Roche Diagnostics, Mannheim, Germany) was performed. The primers and probes used for RHD genotyping were targeted towards exons 7 and 10. For the detection of chromosome Y, primers and probes were targeted for the SRY gene on chromosome Y (Table 1). Amplicon lengths for exons 7, 10 and $S R Y$ were 82, 122 and 137 bp, respectively. All primers and probes were synthesized by TIB MOLBIOL (Berlin, Germany). At least two regions of the $R H D$ gene were used for the complex genetic variant forms of $R H D$. The primers and probes designed for exons 7 and 10 did not permit amplification of a non functional rearranged $R H D$

Table 1. Primers and TaqMan probes.

\begin{tabular}{|c|c|c|}
\hline Exon 7 & $\begin{array}{l}\text { Forward primer } \\
\text { Reverse primer } \\
\text { Probe }\end{array}$ & $\begin{array}{l}\text { 5'-CTC CAT CAT GGG CTA CAA-3' } \\
\text { 5'-CCG GCT CCG ACG GTA TC-3' } \\
\text { 5'-(FAM) AGC AGC ACA ATG TAG ATG ATC TCT CCA (TAMRA)-3' }\end{array}$ \\
\hline Exon 10 & $\begin{array}{l}\text { Forward primer } \\
\text { Reverse primer } \\
\text { Probe }\end{array}$ & $\begin{array}{l}\text { 5'-CCT CTC ACT GTT GCC TGC ATT-3' } \\
\text { 5'-AGT GCC TGC GCG AAC ATT-3' } \\
\text { 5'-(FAM) TAC GTG AGA AAC GCT CAT GAC AGC AAA GTC T (TAMRA)-3' }\end{array}$ \\
\hline SRY & $\begin{array}{l}\text { Forward primer } \\
\text { Reverse primer } \\
\text { Probe }\end{array}$ & $\begin{array}{l}\text { 5'-TGG CGA TTA AGT CAA ATT CGC-3' } \\
\text { 5'-CCC CCT AGT ACC CTG ACA ATG TAT T-3' } \\
\text { 5'-(FAM) AGC AGT AGA GCA GTC AGG GAG GCA GA (TAMRA)-3' }\end{array}$ \\
\hline FOXP1 & $\begin{array}{l}\text { Forward primer } \\
\text { Reverse primer } \\
\text { Probe }\end{array}$ & $\begin{array}{l}\text { 5'-CTG CAA CGA AAC TAA ATT GTG TGA TT-3' } \\
\text { 5'-GGT CCC CGT AAG CTG CTG-3' } \\
\text { 5'-(FAM) TGC TCT CGT TTC TCT TTG GAA CAC CAG T (TAMRA)-3', }\end{array}$ \\
\hline
\end{tabular}


gene, which has been demonstrated in this and in other studies generating positive results in exon 10 .

The $R H D / S R Y$ amplification reactions were set up in a volume of $20 \mu \mathrm{L}$. Each reaction contained $4 \mu \mathrm{L}$ of Light Cycler DNA Master Hybridization Probes (Roche Diagnostics, Basel, Switzerland; 10× concentrated), $100 \mathrm{nM}$ of each probe, and $200 \mathrm{nM}$ of each amplification primer. A $4 \mu \mathrm{L}$ volume of the extracted DNA was used for amplification. Thermal cycling was initiated by a denaturation step of 10 min. at $95{ }^{\circ} \mathrm{C}$, followed by 50 cycles at $95^{\circ} \mathrm{C}$ for 15 seconds and at $60{ }^{\circ} \mathrm{C}$ for 60 seconds. Amplification data were analyzed using the Light-Cycler software (Roche Diagnostics).

A duplicated RHD/SRY PCR was set up for each individual sample. If results in the duplicate tests were inconclusive or all data for the $R H D$ and $S R Y$ genes were negative, the PCR set up was repeated, resulting in a maximum number of four RHD/SRY PCR procedures.

The presence or absence of the fetal RHD gene was determined as follows: first, the samples were examined in duplicate. If both reactions were positive, we considered the fetus was carrying the paternal $R H D$ gene. If both reactions were negative or one of two was positive, the sample was repeated in another duplicate. In total, if the fetal RHD sequence was detectable in two or more of four reactions, the result was scored as positive. Otherwise, it was considered to be negative. Confirmation of our results was performed by the analysis of the serological test on cord blood after delivery or by genotyping the fetal DNA obtained from amniocentesis or CVS. Only samples with cycle threshold $(\mathrm{Ct})$ values of less than 40 were considered positive. The results were finally interpreted if all performed PCR procedures for RHD and SRY were consistent. If the PCR replicates for RHD or SRY were discrepant, the plasma was retested from DNA isolated from the second tube.

For gender detection, the SRY sequence was used to identify male fetal DNA that was present in each sample. The experiment was repeated in three separate reactions. If at least two of the three amplification reactions were positive for the SRY sequence, the fetus was considered to be male. If there was no SRY sequence amplification in all separate reactions, the fetus was considered to be female. The results were confirmed by karyotype, examination after birth or Doppler ultrasound after 20 weeks of gestation.
Table 2. Results of maternal plasma, fetal $\mathrm{RhD}$ and gender.

\begin{tabular}{|c|c|c|c|c|c|}
\hline \multirow[t]{2}{*}{ Case } & \multirow[t]{2}{*}{$\begin{array}{l}\text { Week of } \\
\text { Gestation }\end{array}$} & \multicolumn{2}{|c|}{$\begin{array}{c}\text { Maternal } \\
\text { Plasma }\end{array}$} & \multicolumn{2}{|c|}{$\begin{array}{l}\text { Fetal } \\
\text { RhD }\end{array}$} \\
\hline & & $\mathrm{RhD}$ & Gender & $\mathrm{RhD}$ & Gender \\
\hline 1 & 30 & {$[+]$} & $\mathrm{XX}$ & {$[+]$} & $\mathrm{XX}$ \\
\hline 2 & 38-39 & {$[+]$} & $\mathrm{XX}$ & {$[+]$} & $\mathrm{XX}$ \\
\hline 3 & 9 & {$[-]$} & $\mathrm{XX}$ & {$[-]$} & $\mathrm{XX}$ \\
\hline 4 & $17-18$ & {$[-]$} & $\mathrm{XY}$ & {$[-]$} & $X Y$ \\
\hline 5 & 35 & {$[+]$} & $\mathrm{XY}$ & {$[+]$} & $\mathrm{XY}$ \\
\hline 6 & 35 & {$[+]$} & $\mathrm{XX}$ & {$[+]$} & $\mathrm{XX}$ \\
\hline 7 & 37 & {$[+]$} & $\mathrm{XY}$ & {$[+]$} & $X Y$ \\
\hline 8 & $19-20$ & {$[+]$} & $\mathrm{XX}$ & {$[+]$} & $\mathrm{XX}$ \\
\hline 9 & $34-35$ & {$[-]$} & XX & {$[-]$} & $\mathrm{XX}$ \\
\hline 10 & 35 & {$[-]$} & $\mathrm{XX}$ & {$[-]$} & $\mathrm{XX}$ \\
\hline 11 & 39 & {$[+]$} & $\mathrm{XX}$ & {$[+]$} & $\mathrm{XX}$ \\
\hline 12 & 6 & {$[+]$} & $\mathrm{XX}$ & {$[+]$} & $\mathrm{XX}$ \\
\hline 13 & $36-37$ & {$[-]$} & XX & {$[-]$} & XX \\
\hline 14 & 24 & {$[-]$} & $\mathrm{XX}$ & {$[-]$} & $\mathrm{XX}$ \\
\hline 15 & 37 & {$[+]$} & $\mathrm{XX}$ & {$[+]$} & $\mathrm{XX}$ \\
\hline 16 & 36 & {$[+]$} & $\mathrm{XY}$ & {$[+]$} & $X Y$ \\
\hline 17 & 35 & {$[+]$} & XX & {$[+]$} & XY \\
\hline 18 & 19 & {$[+]$} & $X Y$ & {$[+]$} & $\mathrm{XY}$ \\
\hline 19 & 18 & {$[-]$} & $X Y$ & {$[-]$} & $\mathrm{XY}+21$ \\
\hline 20 & 18 & {$[+]$} & $\mathrm{XY}$ & {$[+]$} & $\mathrm{XY}$ \\
\hline 21 & $16-17$ & {$[+]$} & $\mathrm{XY}$ & {$[+]$} & XY \\
\hline 22 & 22 & {$[+]$} & $\mathrm{XY}$ & {$[+]$} & $\mathrm{XY}$ \\
\hline 23 & 18 & {$[+]$} & $\mathrm{XY}$ & {$[+]$} & $\mathrm{XY}$ \\
\hline 24 & 25 & {$[+]$} & $\mathrm{XY}$ & {$[+]$} & $\mathrm{XY}$ \\
\hline 25 & 17 & {$[+]$} & $\mathrm{XX}$ & {$[+]$} & $\mathrm{XX}$ \\
\hline 26 & 17 & {$[+]$} & $\mathrm{XX}$ & {$[+]$} & $\mathrm{XX}$ \\
\hline 27 & 19 & {$[+]$} & XX & {$[+]$} & XX \\
\hline 28 & 17 & {$[+]$} & $\mathrm{XX}$ & {$[+]$} & $\mathrm{XX}$ \\
\hline 29 & 17 & {$[+]$} & $\mathrm{XX}$ & {$[+]$} & $\mathrm{XX}$ \\
\hline 30 & $17-18$ & {$[-]$} & XX & {$[-]$} & $\mathrm{XX}$ \\
\hline
\end{tabular}

\section{RESULTS}

Non invasive fetal RHD genotyping using cffDNA in maternal plasma was performed in 30 pregnancies. The median gestational age at the time of blood sampling was 25.4 weeks (range 9-39 weeks). 
Serological tests on the infant's red blood cells (RBCs) were performed, and fetal gender was confirmed after delivery. One sample (case 12, whose blood group was found to be $\mathrm{AB} \mathrm{Rh}[+])$ was excluded because of controversial results from repeated serological analyses. Among 29 plasma samples, one was in her first trimester, 15 were in the second trimester and 13 were in the third trimester.

When compared to postpartum serological results, an accuracy rate of $100.0 \%$ was achieved in our prenatal prediction of fetal $\mathrm{RhD}$ status and gender determination from the maternal plasma. No falsenegative or false-positive results were obtained.

Out of 29 cases, 21 were $\mathrm{RhD}[+]$ and eight were $\mathrm{RhD}[-]$. The results are summarized in Table 2. Out of all cases, 12 were male and 17 were female. Nine out of 12 male cases had an SRY-positive PCR amplification in each of the three separate reactions. Of the remaining three male cases, two had SRY-positive amplifications in three separate reactions. Two male fetuses had chromosomal aneuploidies at amniocentesis (47,XXY and 47,XY,+21, respectively).

The SRY amplifications were all negative in three separate reactions in 17 female fetuses. The presence of fetal DNA in 17 female fetuses was shown by establishing a PCR reaction specific for the human FOXP1 DNA sequence. Sex detection of the fetus according to the SRY amplification from maternal plasma showed $100.0 \%$ sensitivity. The earliest gestational week for sex identification was 9 weeks in this study. The fetal RhD status was correctly confirmed by amniocentesis or CVS in 29 of 29 cases with the diagnostic accuracy of $100.0 \%$.

\section{DISCUSSION}

It has become a common practice to offer routine antenatal anti-D prophylaxis, usually at 28-34 weeks of gestation, or within 72 hours after delivery to prevent anti-D immunization in RhD-negative pregnant women. Anti-D prophylaxis is not indicated in about $40.0 \%$ of all RhD-negative cases because the fetus is also $\mathrm{RhD}$-negative. We have shown that real-time PCR analysis of cffDNA in maternal plasma is a feasible and reliable technology after analyzing 29 maternal plasma samples which resulted in sensitivity and specificity rates of $100.0 \%$. These high sensitivity and specificity rates were also achieved in the second and third trimesters.
Due to the high complexity of the Rh system and the possibility of false results, more than one region of the $R H D$ gene is suggested to be examined for RhD typing [11-13]. Therefore, two RHD-specific exons (7 and 10) were amplified, which is importantly below the mean size of circulating cffDNA in maternal serum (range 145-201 bp) [14]. The sizes of the two amplicons are 89 and $73 \mathrm{bp}$ for exons 7 and 10 , respectively. In this study, two regions of the $R H D$ gene was examined for $\mathrm{RhD}$ typing and elimination of false-negative results.

There are several distinctive results concerning the quantification cycle (Cp) values of RHD-positive fetuses. It is accepted that RHD-positive fetus gives $\mathrm{Cp}$ values in the range of $35-40$, and no $\mathrm{Cp}$ values are observed when the fetus is RhD-negative. RouillacLe Sciellour et al. [15] highlighted the presence of a silent variant $R H D$ gene such as the RHD $\Psi$ (pseudogene) in the maternal genome when $\mathrm{Cp}$ values are in the range of 26-30 cycles. They also pointed out different levels of expression of exon 7 and exon 10 of the $R H D$ gene depending on the gestational age. If amplification of exon 7 is [+] but exon 10 is [-], it was suggested that exon 7 PCR was more sensitive than exon 10 PCR in which the result was considered as RHD-positive. This is usually indicative for a sample collected during early pregnancy (less than 10 weeks of gestation) when the level of fetal DNA is low in the mother's plasma. In a completely opposite condition, if exon 7 is [-] but exon $10[+]$ and $\mathrm{Cp}>35$, they emphasized the presence of a Rh variant that could be either RhD-negative or weak or partial D type. The amplification of only exon 7 was suggested to be useful for the determination of the fetal RHD genotype [15]. The discrepancies between the results of exons 7 and 10 might be solved by the third RHD-specific PCR. In our study, Ct values of exons 7 and 10 in $\mathrm{RhD}[-]$ cases did not show amplification, however, $\mathrm{Ct}$ values of both exons were $>35$ in $\mathrm{RhD}[+]$ cases. Insufficient amplification of exon 10 was detected in only two cases by the confirmation of PCR analysis; therefore, amplification solely of exon 7 PCR has been accepted to be indicative of $\mathrm{RhD}$ status.

Towards the end of the third trimester, there is a rapid increase in the amount of circulating cffDNA in maternal plasma $[16,17]$. In this study, exon 7 , exon 10 and SRY DNA copy numbers were significantly increased in parallel with the increasing gestational age as pointed out in the literature. 
The existence of the $S R Y$ and $R H D$ genes definitely indicate the presence of fetal genetic material without considering maternal genome in $\mathrm{Rh}[-]$ pregnant women. In SRY [+] and $\mathrm{RhD}[+]$ cases, the copy number of the $S R Y$ gene was significantly correlated with the copy number of exons 7 and 10 . In addition, the correlation between the exons 7 and 10 in $\mathrm{RhD}[+]$ female fetuses showed that the method used in this study is highly reliable to determine fetal genetic material.

The sensitivity of genotyping fetal DNA from maternal plasma varies in the literature. Bischoff et al. [2] observed a sensitivity of $70.0 \%$ in 20 sensitized RhD [-] pregnant women. Fetal RHD genotyping in another study correctly predicted fetal $\mathrm{Rh}$ status in 92 of $98(94.0 \%)$ cases [3]. By combining amplification of three exons, the concordance rate of fetal RHD genotypes in maternal plasma and newborn with RHD phenotypes at delivery was $100.0 \%$ (99.8\% including one unusual false-positive) in the Belgian group [4]. Since then, numerous groups have reported similar results for fetal RHD genotyping in $\mathrm{RhD}$-negative mothers [5-8] as in the presented study, which indicated a sensitivity and specificity of $100.0 \%$.

Our results have shown that non invasive fetal RHD genotyping can be performed rapidly and reliably using cffDNA in maternal plasma with TaqMan real-time PCR assay with a sensitivity and specifity of $100.0 \%$. The weakness of our study is the low number of tested samples, which could be the reason for the $100 \%$ sensitivity and specificity. A further prospective study with a larger number of samples will be performed in the future to confirm the reliability of this protocol.

Declaration of Interest. The authors report no conflicts of interest. The authors alone are responsible for the content and writing of this article.

\section{REFERENCES}

1. Avent ND, Reid ME. The Rh blood group system: a review. Blood. 2000; 95(2): 375-387.

2. Bischoff FZ, Nguyen DD, Marquéz-Do D, Moise KJ Jr, Simpson JL, Elias S. Noninvasive determination of fetal $\mathrm{RhD}$ status using fetal DNA in maternal serum and PCR. J Soc Gynecol Investig. 1999; 6(2): 64-69.
3. Zhou L, Thorson JA, Nugent C, Davenport RD, Butch SH, Judd WJ. Noninvasive prenatal RHD genotyping by real-time polymerase chain reaction using plasma from D-negative pregnant women. Am J Obstet Gynecol. 2005; 193(6): 1966-1971.

4. Minon JM, Gerard C, Senterre JM, Schaaps JP, Foidart JM. Routine fetal RHD genotyping with maternal plasma: a four-year experience in Belgium. Transfusion. 2008; 48(2): 373-381.

5. Geifman-Holtzman O, Grotegut CA, Gaughan JP. Diagnostic accuracy of noninvasive fetal $\mathrm{Rh}$ genotyping from maternal blood - a metaanalysis. Am J Obstet Gynecol. 2006; 195(4): 1163-1173.

6. Daniels G, Finning K, Martin P, Massey E. Noninvasive prenatal diagnosis of fetal blood group phenotypes: current practice and future prospects. Prenat Diagn. 2009; 29(2): 101-107.

7. Dovč-Drnovšek T, Klemenc P, Toplak N, Blejec T, Bricl I, Rožman P. Reliable determination of fetal RhD status by RHD genotyping from maternal plasma. Transfus Med Hemother. 2013; 40(1): 37-43.

8. Ordoñez E, Rueda L, Cañadas MP, Fuster C, Cirigliano V. Development and validation of multiplex real-time PCR assay for noninvasive prenatal assessment of fetal $\mathrm{RhD}$ status and fetal sex in maternal plasma. Fetal Diagn Ther. 2013; 34(1): 13-18.

9. Legler TJ, Liu Z, Mavrou A, Finning K, Hromadnikova I, Galbiati S, et al. Workshop report on the extraction of foetal DNA from maternal plasma. Prenat Diagn. 2007; 27(9): 824-829.

10. Clausen FB, Krog GR, Rieneck K, Dziegiel $\mathrm{MH}$. Improvement in fetal DNA extraction from maternal plasma. Evaluation of the $\mathrm{Nu}-$ cliSens Magnetic Extraction system and the QIAamp DSP Virus Kit in comparison with the QIAamp DNA Blood Mini Kit. Prenat Diagn. 2007; 27(1): 6-10.

11. Avent ND. The Rhesus blood group system: insights from recent advantages in molecular biology. Transfus Med Rev. 1999; 13(4): 245-266.

12. Daniels G. Human blood groups, 2nd ed. Oxford: Blackwell Science, 2002.

13. Huang C, Liu PZ, Cheng JG. Molecular biology and genetics of the Rh blood group system. Semin Hematol. 2000;37(2): 150-165. 
14. Chan, KC, Zhang J, Hui AB, Wong N, Lau TK, Leung TN, et al. Size distributions of maternal and fetal DNA in maternal plasma. Clin Chem. 2004; 50(1): 88-92.

15. Rouillac-Le Sciellour C, Sérazin V, Brossard Y, Oudin O, Le Van Kim C, Colin Y, et al. Noninvasive fetal RHD genotyping from maternal plasma. Use of a new developed Free DNA Fetal Kit RhD. Transfus Clin Biol. 2007; 14(6): 572-577.
16. Lo YM, Tein MS, Lau TK, Haines CJ, Leung TN, Poon PM, et al. Quantitative analysis of fetal DNA in maternal plasma and serum: implications for noninvasive prenatal diagnosis. Am J Hum Genet. 1998; 62(4): 768-775.

17. Lo YM, Hjelm NM, Fidler C, Sargent IL, Murphy MF, Chamberlain PF, et al. Prenatal diagnosis of fetal $\mathrm{RhD}$ status by molecular analysis of maternal plasma. N Engl J Med. 1998; 339(24): 1734-1738. 